\title{
Study on the Relativity between Airborne Microbes and Environmental Factors in Pearl River Delta' Urban Agglomeration, Guangdong
}

\author{
Zhiqing Zheng \\ School of Geographical Sciences, Guangzhou University, Guangzhou 510006, China \\ E-mail: zhiqingzheng@hotmail.com \\ Xiaobao Xie, Yousheng Ouyang, Chunhua Wang, Haiyan Zeng \& Yiben Chen \\ Guangdong Institute of microbiology, Guangzhou 510070, China
}

Taotao Chen

College of Continuing Education South China University of Technology, Guangzhou 510640, China

Guangdong key task project in scientific and technological research (No.2004b33301005)

\begin{abstract}
In this paper, according to the fieldwork and statistic analysis, the issues for the relativity between airborne microbes and environmental factors in Pearl River delta' Urban Agglomeration, Guangdong are discussed using ecological method in order to research on health prevention and environment control measures in Pearl River delta' Urban.

The results show that as follow:(1) The average content of airborne microbes (fungi and bacteria) in Guangzhou and Dongguan is higher than other 6 cities in Pearl River delta' Urban; the content of bacteria is higher than fungi; outdoor content is higher than indoor content; the average content of airborne microbe in the area without greenbelt is higher than the area with greenbelt; the average content of airborne microbe are higher during spring and summer than other seasons.

(2) There are obvious relativity between the average content of airborne microbes (fungi and bacteria) and environment factors (wind speed, humidity, temperature, total suspended particulate (Tsp); Furthermore, most of those have positive or negative linear relationship.

(3) There are also obvious relativity between the average content of airborne microbes (fungi and bacteria) and the number of person flowrate, car flowrate and condition of afforestation, population density.
\end{abstract}

Keywords: Pearl River delta'Urban Agglomeration, Airborne microbes, Environmental factor, Relativity

\section{Introduction}

Atmosphere is the environment which human being relies for existence and the dissemination medium for proliferation of microorganism and diffusion of disease. Particulates of airborne microbes which include bacteria, fungi, virus, actinomycetes and other microorganisms are an important part of air pollution, and there are close relation between produce from microorganism and human activity. Human activity has biggish influence on City environment, as Human activity rebuilt ground and kinds of facilities. Human and animal' skin and hair can be attached to the small particulates surface of atmospheric Sol. Some airborne microbes can stay through a human skin and bring tremendous damage to human health; even they can also spread via fluxion of air to the farther region and bring human many contagion and disease about upper respiratory tract(Ouyang Yousheng, Xie Xiaobao, 2003). When movement of the atmosphere change, haze will form the particulates of microorganism and non-living meet together. It is possible that it will bring big healthy problem to human and serious second pollutions to the industrial products, such as electronics, the living creature system medicine, food, animal feed and cosmetics...etc, and will also bring bad influence on development of tour industry and dining industry(Wang Chun-hua, Xie Xiao-bao, Zeng Hai-yan, 2007)(J.Nicklin. K.Graeme-Cook, T.Paget \& R.Killington). In addition, the content of microorganism in the atmosphere which can reflect the quality of air condition in the city is an important parameter of atmosphere pollution in the city.

Pearl River Delta covers an area of $47525.4 \mathrm{~km}^{2}$ which is about $26.7 \%$ of Guangdong province, including 14 cities and districs--Guangzhou, ShenZhen, Zhuhai, FoShan, JiangMen, DongGuan, ZhongShan, Huizhou, Huiyang, Huidong, Boluo, Duanzhou distric and Dinghu distric of Zhaoqing, Gaoyao and Sihui. It has a favourable geographical position which has fine natural and economic environment. With the speeding progress of civilization, the Pearl River Delta became one of the most flourishing regions in economic development. Rapid development of urban agglomeration, 
expeditious inflation of population, increase of pollution source from urban agglomeration and locating in south-Asia tropical monsoon area provided a good environment for the reproducing of microorganisms in atmosphere. In recent years, the atmosphere environmental problems in Pearl River Delta become obvious.

The number of haze days in atmosphere year is up to 100 days which is obviously more than in the past. At the same time, virus of SARS and bird-flu strike human beings frequently, which threaten human beings' health and life(Ouyang Yousheng, Xie Xiaobao, 2004)(Ouyang yousheng, xie xiaobao, chen yiben., 2006)(Chen haowen. 1996). Therefore, the problems of the pollution and spread microorganisms in atmosphere, the atmosphere pollution and its protection had become desiderated.

The issues about pollution and distribution of airborne microbes were paid attention by many scholars in recent years, but the issues about the reciprocity between airborne microbes and environment are rarely researched in China, even the research report on the relativity between airborne microbes and environment in Pearl River Delta area is not present. In this paper, according to the fieldwork and statistic analysis, the issues for the relativity between airborne microbes and environmental factor in Pearl River delta Urban, Guangdong are discussed using ecological method in order to research on health prevention and environment control measures in Pearl River delta' Urban.

\section{Method}

\subsection{Collector}

Adopting JWL-IIB Air-Borne Microbial Sampling Apparatus, the samples were collected using principle of inertial impaction, according to air exhausts driving force effect. High-speed airflow comes out as the air goes through slit and eyelet, and make microorganism particulate which suspend in the air to hit the medium and to be collected. Using collected air push the dish revolves, those collected microorganism particulates are distributed equality on medium, in order to rightly measure density of particulates with bacteria in this environment.

\subsection{Location and timing of sample collection}

Air sampling and environmental factors were carried out synchronously in four functional places(key traffic route, commercial pedestrian street, residential district and industrial district) in eight each cities around Pearl River delta' Urban, Guangdong, in four different seasons during 2005 and 2007. The height of sample collected is $1.0 \mathrm{~m}$. The air flux of sample is $20 \mathrm{~L} / \mathrm{min}$ and testing time is around 2-5 minutes. At the same time of sample collecting, meteorological factors (such as atmosphere temperature, humidity, wind speed and intensity of illumination light) and environment factors (person flowrate, car flowrate and condition of afforestation are monitored and recorded.

\subsection{Medium of collecting sample and method of culture}

The collected bacteria in air culture agar substrate, in $30 \pm \mathrm{s} 2{ }^{\circ} \mathrm{C}, 24-48 \mathrm{~h}$; the fungi culture PDA agar substrate, in 25 $\pm 2{ }^{\circ} \mathrm{C}, 3-5$ days; each of them were treated in twice repeat.

\subsection{Data and statistic analysis}

The formula of colony: colony $\mathrm{cfu} / \mathrm{m}^{3}=[$ average colony in even utensil $(\mathrm{N}) \times 1000] \div[$ the air flowrate $(\mathrm{L} / \mathrm{min}) \times$ collecting time(Min)]

Adopting the Spss software for calculation, the number of airborne microbes fungi and bacteria colony, synchronously observational data of meteorological factors which include temperature, humidity, wind speed, and simultaneous atmosphere monitor data of total suspend particulates(TSP) and inhalable particulates(PM10) were analyzed using correlative analysis, Unary Linear Regression analysis and multiple linear regression analysis. At the same time, the statistic and comparative analysis on colony number of fungi and bacteria of airborne microbes and person flowrate and afforestation condition in collected point were carry out.

\section{Results and analysis}

\subsection{Condition of atmospheric microorganism colony numbers and the environment factors in observation point}

Data statistics indicate: The compositor of density of airborne microbes, in 8 cities are Guangzhou> Dongguan> Zhongshan $>$ Foshan $>$ Huizhou $>$ Shenzhen $>$ Jiangmen $>$ Zhuhai; (See table 1)According to the content of microorganism from each observation point, bacteria is the most in atmospheric microorganism which is 299378 $\mathrm{cfu} / \mathrm{m}^{3}$, about $78.2 \%$ of the airborne microbes, total amount, generally $200-300 \%$ of fungi $\left(126113 \mathrm{cfu} / \mathrm{m}^{3}\right.$ ); (See table 1.2) See from the space distribution, compare different function area: transportation junction $>$ industrial district $>$ business district $>$ residential district $>$ green belt, there are the most content of fungi and bacteria in transportation junction.(See table3) The content of fungi and bacteria indoor $\left(1694.76 \mathrm{cfu} / \mathrm{m}^{3}\right)$ are more than outdoor's environment $\left(1368.31 \mathrm{cfu} / \mathrm{m}^{3}\right.$, $)$; furthermore the quantity of bacteria is much more; the content in afforestation area is less than that in non-afforestation area and the air quality is much better.(See table2) See from time distribution, compare of total average content of bacteria and fungi: Spring $>$ summer $>$ autumn $>$ winter; average content of fungi: Spring $>$ summer $>$ winter $>$ autumn; average content of bacteria: Spring $>$ autumn $>$ summer $>$ winter.(See table 4) 
The main reasons that above mentioned are relative with the variety of development of urbanization, city climate and environmental factors. Guangzhou is center city of Pearl River Delta, whose business economy is flourishing and person flowrate and materials circulation are more concentrated; Development of urbanization in Dongguan was very fast in last 20 years, whose industry is dense and population is more; therefore airborne microbes, content of both cities are higher than others in Pearl River Delta' Urban. Place Pearl River Delta which located in subtropical monsoon climate zones, there are high temperature and humidity in whole year, especially in spring and summer when the big change of temperature and humidity happen frequently, and consequently airborne microbes content in spring and summer are much higher than other two seasons. Northern Hemisphere turn warm in spring and summer, the air pressure descends (1001.3-1003.1 HPA), the temperature rise $\left(21-29{ }^{\circ} \mathrm{C}\right)$ gradually, the degrees of humidity enlargement (69-81\%), all of these are very benefic to the increase of fungi and bacteria. In these seasons, the variety of weather is usually vigorous, the wind speed is weak, the air circulate is not good, the city population is concentrated, the exhaust capacity of industry pollution material is great, total suspending particulates and inhalable particulates are increasable (there is respectively $182-239 \mathrm{mg} / \mathrm{m}^{3}, 39.8-63.5 \mathrm{mg} / \mathrm{m}^{3}$ ) in the air, all of these are the reasons that the many content of fungi and bacteria bring about the problem that the air pollution increased. It follows that concentrated population and weak Ventilation are two important factors for the content of airborne microbes in indoor environment; Rapid development of industrialization, concentration of the person flowrate and materials circulation, high air temperature and humidity, condition of afforestation, all of these are influence factors for content of airborne microbes, in outdoors environment, particularly it is obvious in the place which is rapid development of urban industrialization and high person flowrate, in the spring and summer when the weather drastic changes.

\subsection{Relativity with meteorological factors and atmosphere particulates}

\subsubsection{Relativity analysis}

Relativity analysis of statistical data shows that fungi, bacteria and temperature, humidity are good relativity in the majority cities of the Pearl River Delta' Urban (especially Shenzhen, Huizhou), but there are obvious relativity with wind speed only in individual cities. The relativity coefficient (R) about temperature and fungi, the total number of bacteria in four seasons is between $0.588-0.988$, and the relativity coefficient $(\mathrm{R})$ with humidity between $0.660-0.944$ (see table 5)

In Guangzhou City, the relativity coefficient about fungi and total number of bacteria with the meteorological factors is between $0.28-0.36$, which is general relativity. The relativity coefficient $(\mathrm{R})$ about fungi and total number of bacteria with pressure are respectively $0.605,0.050$; The relativity coefficient with sunshine hours are $0.239,0.227$; The relativity coefficient with inhalable particulates are $0.525,0.081$; with total suspended particulates are $0.388,-0.044$, these results show that there is obvious relativity between total numbers of fungi and total pressure, inhalable particulates, however value $\mathrm{R}$ is bigger which may be the numerical sampling error.

\subsubsection{Unary Linear Regression analysis}

According to the content of airborne microbes and meteorological factors is counted as variable, the regression equation was established, and the results show that:

The Unary Linear Regression equation was established base on the relationship between Fungi, bacteria and temperature is counted as variables. There respectively relativity of three seasons is obvious, and two tests (P \& T value) indicated that confidence level is high. Unary Linear Regression model as follows:

$\begin{array}{lllll}\text { Fungi: } \quad \text { autumn } \mathrm{y}=-47.673 \mathrm{x}+1649.177 & \mathrm{p}=0.019 & \mathrm{~T}=0.004 \\ \text { winter } \mathrm{Y}=7.468 \mathrm{x}+318.515 & \mathrm{p}=0.483, & \mathrm{~T}=0.133 & \\ \text { summer } \mathrm{y}=129.102 \mathrm{x}+(-2922.550) & \mathrm{p}=0.440 & \mathrm{~T}=0.607 & \\ \text { Bacteria: } & \text { spring } \mathrm{y}=-114.413 \mathrm{x}+4546 & \mathrm{p}=0.096 & \mathrm{~T}=0.18 \\ \text { autumn } \mathrm{y}=-37.013 \mathrm{x}+2567.420 & \mathrm{p}=0.521 & \mathrm{~T}=0.196 & \\ \text { summer } \mathrm{Y}=-273.599 \mathrm{x}=8786.616 & \mathrm{p}=0.055, & \mathrm{~T}=0.025 & \end{array}$

The Unary Linear Regression equation was established base on the relationship between Fungi, bacteria and humidity is counted as variables. There relativity of three seasons for fungi and four seasons for bacteria are obvious, and confidence level is high. Unary Linear Regression model as follows:

$\begin{array}{lcccc}\text { Fungi: } \quad \text { autumn } \mathrm{y}=-479.170 \mathrm{x}+608.646 & \mathrm{p}=0.480 & \mathrm{~T}=0.100 \\ \text { winter } \mathrm{Y}=23.035 \mathrm{x} & +420.032 & \mathrm{p}=0.002 & \mathrm{~T}=0.001 & \\ \text { summer } \mathrm{T}=-2580.393 \mathrm{x}+2848 & \mathrm{p}=0.695 & \mathrm{~T}=0.30 & \\ \text { Bacteria: } & \text { spring } \mathrm{Y}=6033.573 \mathrm{x}+(-2466.473) & \mathrm{p}=0.065 & \mathrm{~T}=0.246 \\ \text { winter } \mathrm{Y}=66.145 \mathrm{X} & +1051.610 & \mathrm{P}=0.124 & \mathrm{~T}=0.01 & \end{array}$




$$
\begin{array}{lcc}
\text { summer } \mathrm{y}=-646.679 \mathrm{x}+1659.634 & \mathrm{p}=0.776 & \mathrm{~T}=0.186 \\
\text { autumn } \mathrm{Y}=-3456.121 \mathrm{x}+3189.715 & \mathrm{p}=0.46 & \mathrm{~T}=0.206
\end{array}
$$

The once basic linear regression equation was established base on the relationship between Fungi, bacteria and wind speed is counted as variables. There relativity of four seasons for fungi and bacteria are obvious, and confidence level is

\begin{tabular}{|c|c|c|c|}
\hline spring $Y=-201.394+103$ & 44 & $\mathrm{p}=0.046$ & $\mathrm{~T}=0.001$ \\
\hline summer $y=-178.655 x+1559.230$ & $\mathrm{p}=0.508$ & $\mathrm{~T}=0.037$ & \\
\hline autumn $y=33.046 x+320.220$ & $\mathrm{p}=0.412$ & $\mathrm{~T}=0.001$ & \\
\hline winter $y=-134.023 x+808.465$ & $\mathrm{p}=0.287$ & $\mathrm{~T}=0.001$ & \\
\hline Bacteria: spring $y=-2580.393 x+2$ & & $\mathrm{p}=0.695$ & $\mathrm{~T}=0.30$ \\
\hline summer $y=-97.190 x+1473.108$ & $\mathrm{p}=0.392$ & $\mathrm{~T}=0.001$ & \\
\hline autumn $y=178.644 x+1171.068$ & $\mathrm{p}=0.521$ & $\mathrm{~T}=0.008$ & \\
\hline winter $y=-1119.140 x+3537.788$ & $\mathrm{p}=0.132$ & $\mathrm{~T}=0.006$ & \\
\hline
\end{tabular}
high. Unary Linear Regression regression model as follows:

Above Unary Linear Regression regression analysis showed that fungi, bacteria and meteorological factors such as temperature, humidity, wind speed have a significant positive or negative relativity associated linear relationship. Because temperature in summer, high humidity, which are appropriate environmental conditions for the growth of bacteria and fungi, they propagated rapidly, which resulted in increased urban air pollution, and especially there are obvious in the area with high population and heavy traffic. In autumn and winter with the weather of low temperature and dry climate, the growth of fungi and bacteria are affected by climate change, and those resulted in the relatively low content of airborne microbes. Meteorological factors such as temperature, humidity and wind speed are main factors affect on the content of airborne microbes. Temperature or humidity increase, the content of airborne microbes, will increase at the same time. Wind speed is week $(0.3-1.0 \mathrm{~m} / \mathrm{s})$; the content of airborne microbes, is high, especially in summer and winter.

3.2.3 Multiple linear regression analysis

Base on the variable relationship between content of atmospheric fungi, bacteria in the Pearl River Delta' Urban agglomeration and meteorological factors, multiple linear regression equation were established. Statistical analysis shows that the linear relationship between airborne microbes in Pearl River Delta' Urban agglomeration and meteorological factors include temperature, humidity, wind velocity are obviously. Base on the relationship between total number of atmospheric fungi, bacteria and temperature, humidity, wind velocity, the multiple linear regression analysis is higher credibility, especially in spring, autumn and winter.

Base on the variables relationships between content of atmospheric fungi, bacteria from seven cities in the Pearl River Delta' Urban and meteorological factors, the multivariate linear regression equation is established. According to the test, confidence level is high. The multiple linear regression model as follows:

Fungi:

$\begin{array}{lll}\text { spring } & \mathrm{T}=-14.542 \mathrm{x}+(-2085.143) \mathrm{y}+(-21.5 .416) \mathrm{z}+2879.994 & \mathrm{p}=0.249 \\ \text { autumn } & \mathrm{T}=-48.687 \mathrm{x}+(-588.400) \mathrm{y}+3.2652 \mathrm{z}+1985.586 & \mathrm{p}=0.102 \\ \text { winter } & \mathrm{T}=-42.714 \mathrm{x}+12.882 \mathrm{y}+55.640+1583.276 & \mathrm{p}=0.216\end{array}$

Bacteria: $\quad$ spring $\mathrm{T}=389.877 \mathrm{x}+27800.688 \mathrm{y}+(-1188.866) \mathrm{z}+(-23739.7) \quad \mathrm{p}=0.083$

autumn $\mathrm{T}=-284.34 \mathrm{x}+(-417.745) \mathrm{y}+(-4.389) \mathrm{z}+11298.805 \quad \mathrm{p}=0.220$

winter $\mathrm{T}=-263.802 \mathrm{x}+(-12.260) \mathrm{y}+(-218.366) \mathrm{z}+8991.570 \quad \mathrm{p}=0.086$

Base on the variables relationships between average content of atmospheric fungi, bacteria at the same day in Guangzhou and daily mean temperature, daily mean humidity, daily mean wind speed, daily mean air pressure, daily sunshine hours, inhalable particulates(PM10) and total suspended particulates(TSP), the multiple linear regression model were established. According to the test, confidence level is high. The multiple linear regression model as follows:

Fungi:

$\mathrm{T}=26.623 \mathrm{x}+25.176 \mathrm{y}+(-0.356) \mathrm{z}+39.682 \mathrm{i}+26.563 \mathrm{j}+11.122 \mathrm{k}+(-3.056) \mathrm{l}+(-260471)$

$\mathrm{P}=0.385 \quad \mathrm{~T}=0.132$

\section{Bacteria:}

$\mathrm{T}=196.742 \mathrm{x}+165.346 \mathrm{y}+(-36.846) \mathrm{z}+186.759 \mathrm{i}+(-690.763) \mathrm{j}+(-82.593) \mathrm{k}+71.6821+(-1660282)$

$\mathrm{P}=0.078 \quad \mathrm{~T}=0.026$ 
Guangzhou and the major cities in Pearl River Delta' Urban agglomeration as an example, according to test the absolute value of statistics $\mathrm{T}$ ( or $\mathrm{F}=\mathrm{T} 20$ ) in the condition that regression coefficient is whether zero or not, the importance of each variable are ranked (see Table 6. 7. 8). It showed that changes of wind speed in 7 Pearl River Delta cities in the spring and summer have the greatest impact on the air concentration content of fungi and bacteria. However, the changes of temperature in the autumn and winter have greatest impact on the air concentration content of fungi and bacteria.

The importance of environmental factors in Guangzhou City is ranked as follow: temperature $>$ average pressure $>$ average humidity $>$ total suspended particulates $>$ inhalable particulates $>$ average wind velocity $>$ sunshine hours. the average temperature is an important factors impact on the content of airborne microbes,

\subsection{Relative with the environmental factors such as population, movement of vehicles and conditions of afforestation}

Statistics of survey data (see Table 9) show that: the content of airborne microbes, are much more in the area such as commercial centre with heavy traffic, railway station and coach station. The main reasons for that are high car flowrate and person flowrate. The content of airborne microbes, in ticket lobby of railway station and coach station are obviously more than outside the station. Total average indoor airborne microbes, are $2574 \mathrm{cfu} / \mathrm{m}^{3}$ and the total average number of outdoor airborne microbes, are $1580 \mathrm{cfu} / \mathrm{m}^{3}$, the main reasons of those are due to poor indoor air flow, so many people and crowded environment. There are great difference on the content of airborne microbes, between green belt and non green belt area. The content of airborne microbes, in greenbelt areas are less than those in non green belt areas. (See Table 9) Analyze on heavy traffic area, the content of airborne microbes, of railway Station and Terminal Plaza where is non greenbelt is $3258 \mathrm{cfu} / \mathrm{m}^{3}$; however, this in the roadways with better greenbelt is $3061 \mathrm{cfu} / \mathrm{m}^{3}$; Analyze on the functional areas, the content of airborne microbes, is relatively low which is $4700 \mathrm{cfu} / \mathrm{m}^{3}$ in Shenzhen Wetland Bay Park area which is near the beach has better environment, better condition of ventilation and less flowrate of person and car. However, the content in the heavy traffic area is $15210 \mathrm{cfu} / \mathrm{m}^{3}, 21340 \mathrm{cfu} / \mathrm{m}^{3}$, and the content of airborne microbes, in the commercial area which is $15800 \mathrm{cfu} / \mathrm{m}^{3}$ is higher than other areas.

\section{Conclusion and Discussion}

Statistics on analysis of monitoring data shows that the content of airborne microbes, is relatively high in Guangzhou and Dongguan of Pearl River Delta' Urban agglomeration, thereinto bacteria is more than fungi and the content of airborne microbes, which are indoor higher than outdoor and non greenbelt areas are more than greenbelt areas, are relatively high in spring and summer.

Mathematical Statistics on the relativity analysis, Unary Linear Regression and multiple linear regression analysis indicates that the atmospheric environmental factors include wind speed, humidity, temperature, total suspended particulates(TSP) are obviously relative with the average content of airborne microbes fungi and bacteria, and most of those are positive or negative linearity relations. Temperature, wind speed is the most important environmental factors on the content of airborne microbes,. Comparative analysis of the statistical data shows that the population flowrate, condition of afforestation are obviously relative with the content of airborne microbes, Prevention and control on atmospheric pollution and microbiological hazards have become main research topics on health and epidemic prevention and control of atmospheric pollution(Ouyang yousheng, xie xiaobao, chen yiben., 2006)(Ren qiwen, wang cheng tun. Guanghua, 2006)(Liyong, 2007). Rapid development of the Pearl River Delta cities, high concentration of the population and quality of living environment, all of these impact directly on the people's health, hygiene and disease control and implementation of environmental improvement, and consequently the future should be further strengthen research in this area.

In spring and autumn, the meteorological factors such as temperature, humidity, pressure and environmental factors change greatly and it is also reproduction season for fungi and bacteria. We should strengthen work on health and epidemic prevention, do well in sanitation of the ground, improve indoor ventilation and illumination, improve urban traffic conditions, control emissions of pollution, do well in virescence and beautifying the environment and strengthen the air disinfection in order to improve the environmental quality of urban agglomeration in the Pearl River Delta' Urban.

\section{References}

Chen, haowen. (1996). The content of air borene microbial particles over the delata and estuarine area of zhujiang river, Tropical Ocean, 15(3).76-96.

J.Nicklin. K.Graeme-Cook, T.Paget \& R.Killington lin zhilan translate microbiology Science Press, pp.136-149.

Liyong. (2007). The Correlativity Research of the Xu Zhou City Airborne Microbes Contaminates, Environmental Science and Management, (07). pp. 33-37.

Ouyang, yousheng, xie, xiaobao, chen, yiben. (2006). The Concentration and Variation of Airborne Microbe in Guangzhou City, Microbiology, 33(3): pp. 47-51. 
Ouyang, Yousheng, Xie, Xiaobao. (2003). Determination of airborne microbial cancentration around key rtaffic route in guangzhou urbandistricts, Chinese Journal of health laboratory technology, 13(6): pp.692-693.

Ren, qiwen, wang, cheng tun. (2006). Guanghua Airborne Particulates in Urban Greenland and Its Relationship with Airborne Microbes, Urban Environment \& Urban Ecology, 19(5): pp.22-25.

Wang, Chun-hua, Xie Xiao-bao, Zeng Hai-yan. (2007). Investigation on situation of air-borne microbes in Dongguan City, Chinese Journal of Health Laboratory Technology, 17 (10): pp.1770-1777.

$\mathrm{Xu}$, jianhua. (2002). Mathematical methods in contemporary geography $\left(2^{\text {th }}\right.$ ed) Peking Higher education press, pp.37-47.

Table 1. The contents of fungi and bacteria in 8 cities in four seasons $\left(\mathrm{cfu} / \mathrm{m}^{3}\right)$

\begin{tabular}{|l|l|l|l|l|l|}
\hline Location & $\begin{array}{l}\text { fungi } \\
\left(\mathrm{cfu} / \mathrm{m}^{3}\right)\end{array}$ & $\begin{array}{l}\text { Ratio of fungi } \\
(\%)\end{array}$ & $\begin{array}{l}\text { Bacteria } \\
\left(\mathrm{cfu} / \mathrm{m}^{3}\right)\end{array}$ & $\begin{array}{l}\text { Ratio of Bacteria } \\
(\%)\end{array}$ & $\begin{array}{l}\text { Total number of } \\
\text { microorganism }\left(\mathrm{cfu} / \mathrm{m}^{3}\right)\end{array}$ \\
\hline Guangzhou & 32176 & 19.54 & 132465 & 80.46 & 164641 \\
\hline Dongguan & 17980 & 21.18 & 66928 & 78.82 & 84908 \\
\hline Shenzhen & 8206 & 29.53 & 19583 & 70.47 & 27789 \\
\hline foushan & 22803 & 58.33 & 16290 & 41.67 & 39093 \\
\hline Zhuhai & 3990 & 26.97 & 10803 & 73.03 & 14793 \\
\hline Jiangmen & 6853 & 32.01 & 14553 & 67.99 & 21406 \\
\hline Huizhou & 7341 & 24.33 & 22827 & 75.67 & 30168 \\
\hline Zhong shan & 26764 & 62.69 & 15929 & 37.31 & 42693 \\
\hline Total up & 126113 & 32.95 & 299378 & 78.21 & 382798 \\
\hline
\end{tabular}

Table 2. Comparison of average contents of fungi and_bacteria in main cities base on space distribution (cfu/ $\left.\mathrm{m}^{3}\right)$

\begin{tabular}{|l|l|l|l|l|}
\hline Region & $\begin{array}{l}\text { Indoor } \\
\left(\mathrm{cfu} / \mathrm{m}^{3}\right)\end{array}$ & $\begin{array}{l}\text { Outdoor } \\
\left(\mathrm{cfu} / \mathrm{m}^{3}\right)\end{array}$ & $\begin{array}{l}\text { green belt } \\
\left(\mathrm{cfu} / \mathrm{m}^{3}\right)\end{array}$ & $\begin{array}{l}\text { non-green belt } \\
\left(\mathrm{cfu} / \mathrm{m}^{3}\right)\end{array}$ \\
\hline $\begin{array}{l}7 \text { cities in Pearl } \\
\text { River delta }\end{array}$ & 1694.76 & 1362.31 & 1565 & 1689 \\
\hline Guangzhou & $\begin{array}{l}2574 \\
\text { (bacteria 1950, } \\
\text { fungi 624) }\end{array}$ & $\begin{array}{l}1580 \\
\text { (fungi 462 } \\
\text { bacteria 1118) }\end{array}$ & $\begin{array}{l}\text { 15210 } \\
\text { (fungi 1889 } \\
\text { bacteria 13321) }\end{array}$ & 21340 \\
\hline Shenzhen & $\begin{array}{l}13760 \\
\text { (fungi 2413, }\end{array}$ & & \\
\hline
\end{tabular}

Table 3. The contents of fungi and_bacteria in function district in 8 cities $\left(\mathrm{cfu} / \mathrm{m}^{3}\right)$

\begin{tabular}{|l|l|l|l|}
\hline Functional district; & $\begin{array}{l}\text { Average content } \\
\text { of bacteria }\end{array}$ & $\begin{array}{l}\text { Average content } \\
\text { of fungi }\end{array}$ & $\begin{array}{l}\text { Total number } \\
\text { microorganism }\left(\mathrm{cfu} / \mathrm{m}^{3}\right)\end{array}$ \\
\hline In Traffic & 1456.95 & 726.83 & 2183.78 \\
\hline Out of traffic & 6147.714 & 6807.464 & 12955.18 \\
\hline Business centre & 1093.296 & 381.6296 & 1474.926 \\
\hline Residential district & 1271.875 & 1203.333 & 2475.208 \\
\hline Industrial district & 2164.313 & 764.1875 & 2928.5 \\
\hline Green belt & 479.875 & 217.375 & 697.25 \\
\hline Metro gate & 312.75 & 125.125 & 437.875 \\
\hline Total & 12926.77 & 10225.94 & 23152.72 \\
\hline
\end{tabular}


Table 4. Contens of airborne microbes in different season of 8 cities $\left(\mathrm{cfu} / \mathrm{m}^{3}\right)$

\begin{tabular}{|l|l|l|l|l|}
\hline Item & Spring & Summer & Autumn & Winter \\
\hline Fungi & 26121 & 23234 & 11219 & 18598 \\
\hline Bacteria & 88909 & 83022 & 83944 & 35450 \\
\hline Total & 115030 & 106256 & 95163 & 54048 \\
\hline
\end{tabular}

Table 5. The relativity between the meteorological factors (temperature, hmidity, wind speed and the season and Airborne microbe, (fungi, bacteria) in main cities

\begin{tabular}{|c|c|c|c|c|c|c|c|}
\hline City & Time & $\begin{array}{l}\text { temperature \& } \\
\text { fungi } \mathbf{R}\end{array}$ & $\begin{array}{l}\text { temperature } \quad \& \\
\text { bacteria } \mathbf{R}\end{array}$ & $\begin{array}{l}\text { humidity } \quad \& \\
\text { fungi } \mathbf{R}\end{array}$ & $\begin{array}{l}\text { humidity } \quad \& \\
\text { bacteria } \mathbf{R}\end{array}$ & $\begin{array}{l}\text { Wind speed \& } \\
\text { bacteria } \mathbf{R}\end{array}$ & $\begin{array}{l}\text { Wind speed } \\
\text { \& fungi } \mathbf{R}\end{array}$ \\
\hline $\begin{array}{l}\text { Guang } \\
\text { zhou }\end{array}$ & $\begin{array}{l}\text { all } \\
\text { year }\end{array}$ & 0.348 & 0.325 & -0.350 & -0.362 & -0.11 & 0.28 \\
\hline $\begin{array}{l}\text { Shen } \\
\text { zhen }\end{array}$ & $\begin{array}{l}\mathrm{Sp} \\
\mathrm{Su} \\
\mathrm{Au} \\
\mathrm{wi}\end{array}$ & $\begin{array}{l}0.606 \\
0.693 \\
0.803 \\
0.929\end{array}$ & $\begin{array}{l}0.352 \\
-0.731 \\
-0.729 \\
-0.464\end{array}$ & $\begin{array}{l}-0.759 \\
-0.668 \\
0.943 \\
-0.416\end{array}$ & $\begin{array}{l}-0.638 \\
-0.729 \\
0.208 \\
-0.723\end{array}$ & $\begin{array}{l}0.448 \\
0.200 \\
-0.718\end{array}$ & $\begin{array}{l}0.173 \\
-0.431 \\
-0.099\end{array}$ \\
\hline Jiangmen & $\begin{array}{l}\mathrm{Sp} \\
\mathrm{Su} \\
\mathrm{Au} \\
\text { wi }\end{array}$ & $\begin{array}{l}0.803, \\
0.973 \\
0.340 \\
-0.7509\end{array}$ & $\begin{array}{r}-0.090 \\
-0.578 \\
-0.812 \\
-0.534\end{array}$ & $\begin{array}{l}-0.034 \\
0.961 \\
-0.276 \\
-0.373\end{array}$ & $\begin{array}{l}0.912 \\
0.5747 \\
0.679 \\
-0.366\end{array}$ & & \\
\hline $\begin{array}{l}\text { Hui } \\
\text { zhou }\end{array}$ & $\begin{array}{l}\mathrm{Sp} \\
\mathrm{Su} \\
\mathrm{Au} \\
\text { wi }\end{array}$ & $\begin{array}{l}-0.889 \\
0.617 \\
-0.982 \\
-0.547\end{array}$ & $\begin{array}{l}-0.862 \\
0.047 \\
-0.623 \\
-0.688\end{array}$ & $\begin{array}{l}0.954 \\
-0.345 \\
0.486 \\
-0.337\end{array}$ & $\begin{array}{l}0.916 \\
-0.014 \\
0.987 \\
-0.395\end{array}$ & $\begin{array}{l}-0.309 \\
0.176\end{array}$ & $\begin{array}{l}-0.568 \\
0.866\end{array}$ \\
\hline $\begin{array}{l}\text { Zhu } \\
\text { hai }\end{array}$ & $\begin{array}{l}\mathrm{Sp} \\
\mathrm{Su} \\
\mathrm{Au} \\
\text { wi }\end{array}$ & $\begin{array}{l}-0.599 \\
-0.549 \\
0.180 \\
0.465\end{array}$ & $\begin{array}{l}-0.234 \\
0.7125 \\
-0.496 \\
0.486\end{array}$ & $\begin{array}{l}0.495 \\
0.624 \\
-0.063 \\
-0.545\end{array}$ & $\begin{array}{l}0.058 \\
-0.848 \\
0.237 \\
-0.988\end{array}$ & 0.3999 & -0.807 \\
\hline $\begin{array}{l}\text { Zhong } \\
\text { shan }\end{array}$ & $\begin{array}{l}\mathrm{Sp} \\
\mathrm{Su} \\
\mathrm{Au} \\
\mathrm{wi}\end{array}$ & $\begin{array}{c}0.896 \\
0.297 \\
-0.939 \\
-0.834\end{array}$ & $\begin{array}{l}-0.642 \\
0.822 \\
0.961 \\
0.324\end{array}$ & $\begin{array}{l}-0.905 \\
-0.064 \\
-1.900 \\
0.137\end{array}$ & $\begin{array}{l}0.753 \\
-0.249 \\
0.024 \\
-0.604\end{array}$ & -0.2728 & 0.3486 \\
\hline $\begin{array}{l}\text { Dong } \\
\text { guan }\end{array}$ & $\begin{array}{l}\mathrm{Sp} \\
\mathrm{Su} \\
\mathrm{Au} \\
\mathrm{wi}\end{array}$ & $\begin{array}{r}-0.176 \\
-0.306 \\
-0.694 \\
-0.162\end{array}$ & $\begin{array}{l}0.767 \\
0.010 \\
-0.921 \\
-0.333\end{array}$ & $\begin{array}{l}-0.14419 \\
0.412 \\
0.718 \\
0.584\end{array}$ & $\begin{array}{l}0.537 \\
0.114 \\
0.922 \\
0.038\end{array}$ & $\begin{array}{l}-0.367 \\
-0.822 \\
0.385 \\
0.962\end{array}$ & $\begin{array}{r}-0.815 \\
-0.628 \\
0.0751 \\
0.6471\end{array}$ \\
\hline $\begin{array}{l}\text { Fo } \\
\text { shan }\end{array}$ & $\begin{array}{l}\mathrm{Sp} \\
\mathrm{Su} \\
\mathrm{Au} \\
\mathrm{wi}\end{array}$ & $\begin{array}{r}-0.0940 \\
-0.0940 \\
-0.0940 \\
-0.0940\end{array}$ & $\begin{array}{l}0.828 \\
-0.122 \\
-0.094 \\
-0.094\end{array}$ & $\begin{array}{r}-0.050 \\
-0.050 \\
-0.050 \\
-0.050\end{array}$ & $\begin{array}{l}-0.822 \\
0.1637 \\
-0.050 \\
-0.050\end{array}$ & $\begin{array}{l}-0.217 \\
-0.411 \\
-0.411\end{array}$ & $\begin{array}{r}-0.411 \\
-0.411 \\
-0.411 \\
-0.411\end{array}$ \\
\hline
\end{tabular}


Table 6. Rank of importance of each environmental factor for contents of fungi in Guangzhou

\begin{tabular}{|l|l|l|l|l|l|l|l|}
\hline $\begin{array}{l}\text { Confident } \\
\text { level }\end{array}$ & $\begin{array}{l}\text { Average } \\
\text { temperature }\end{array}$ & $\begin{array}{l}\text { Average_air } \\
\text { pressure }\end{array}$ & $\begin{array}{l}\text { average } \\
\text { humidity }\end{array}$ & $\begin{array}{l}\text { Average } \\
\text { Wind } \\
\text { speed }\end{array}$ & $\begin{array}{l}\text { sunshin } \\
\text { e hours }\end{array}$ & $\begin{array}{l}\text { Total } \\
\text { suspended } \\
\text { particulates }\end{array}$ & $\begin{array}{l}\text { inhalable } \\
\text { particulates }\end{array}$ \\
\hline value T & 5.219 & 4.208 & -3.322 & 1.401 & -1.395 & 3.058 & -2.332 \\
\hline value F & 27.238 & 17.707 & 11.036 & 1.963 & 1.946 & 9.351 & 5.438 \\
\hline rank & 1 & 2 & 3 & 6 & 7 & 4 & 5 \\
\hline
\end{tabular}

Table 7. Rank of importance of each environmental factor for contents of bacteria in Guangzhou

\begin{tabular}{|l|l|l|l|l|l|l|l|}
\hline $\begin{array}{l}\text { Confident } \\
\text { level }\end{array}$ & $\begin{array}{l}\text { average } \\
\text { temperature }\end{array}$ & $\begin{array}{l}\text { Averag air } \\
\text { pressure }\end{array}$ & $\begin{array}{l}\text { averag } \\
\text { humidity }\end{array}$ & $\begin{array}{l}\text { Average } \\
\text { Wind speed }\end{array}$ & $\begin{array}{l}\text { sunshine } \\
\text { hours }\end{array}$ & $\begin{array}{l}\text { Total suspended } \\
\text { particulates }\end{array}$ & $\begin{array}{l}\text { inhalable } \\
\text { particulates }\end{array}$ \\
\hline value T & 2.248 & 2.037 & 0.407 & 0.947 & 0.043 & 0.415 & 0.999 \\
\hline value F & 5.054 & 4.149 & 0.166 & 0.897 & 0.002 & 0.172 & 0.998 \\
\hline rank & 1 & 2 & 6 & 4 & 7 & 5 & 3 \\
\hline
\end{tabular}

Table 8. Rank of importance of environmental factors in four seasons in 7 cities of Pearl River delta

\begin{tabular}{|l|l|l|l|l|l|l|l|l|}
\hline Fungi & Time & $\begin{array}{l}\text { Wind } \\
\text { speed }\end{array}$ & Temperature & Humidity & Bacteria & $\begin{array}{l}\text { Wind } \\
\text { speed }\end{array}$ & Temperature & Humidity \\
\hline value T & spring & -1.772 & -0.289 & -0.756 & value T & -1.446 & 1.145 & 1.492 \\
\hline value F & & 3.314 & 0.084 & 0.572 & value F & 2.091 & 1.311 & 2.226 \\
\hline rank & & 1 & 3 & 2 & & 1 & 3 & 2 \\
\hline value T & summer & 0.682 & 0.295 & 0.242 & value T & -0.920 & 0.497 & 0.352 \\
\hline value F & & 0.465 & 0.087 & 0.059 & value F & 0.846 & 0.247 & 0.124 \\
\hline rank & & 1 & 2 & 3 & & 1 & 2 & 3 \\
\hline value T & autumn & 0.083 & -2.391 & 0.914 & value T & 0.016 & -1.958 & 0.910 \\
\hline value F & & 0.007 & 5.177 & 0.835 & value F & 0.0003 & 3.834 & 0.828 \\
\hline rank & & 3 & 1 & 2 & & 3 & 1 & 2 \\
\hline value T & winter & 0.483 & -1.682 & 1.585 & value T & 0.262 & -1.682 & 0.209 \\
\hline value F & & 0.233 & 2.829 & 2.512 & value F & 0.069 & 2.829 & 0.044 \\
\hline rank & & 3 & 1 & 2 & & 3 & 1 & 2 \\
\hline
\end{tabular}

Table 9. The relationship between average content of airborne microbes, and the environmental factors (condition of afforestation, population flowrate and car flowrate)

\begin{tabular}{|c|c|c|c|}
\hline Location & $\begin{array}{l}\text { Content of airborne } \\
\text { microbe, }\left(\mathrm{cfu} / \mathrm{m}^{3}\right)\end{array}$ & $\begin{array}{l}\text { Condition of population and } \\
\text { car flowrate }\end{array}$ & Condition of afforestation \\
\hline $\begin{array}{l}\text { Gate of Shenzhen railway } \\
\text { station }\end{array}$ & 15210 & $\begin{array}{l}\text { Many automobile and } \\
\text { people }\end{array}$ & $\begin{array}{l}\text { Many building, } \\
\text { but lack of afforestation }\end{array}$ \\
\hline Shenzhen swamp park & 4700 & Less automobile and people & Close to sea and open sward \\
\hline Shenzhen business center & 15800 & many population flowrate & Dense building and less green belt \\
\hline $\begin{array}{l}\text { Non green belts in } \\
\text { Guangzhou and Shenzhen }\end{array}$ & 23029 & $\begin{array}{l}\text { Many automobile and } \\
\text { people }\end{array}$ & Lack of afforestation \\
\hline $\begin{array}{l}\text { park and green belts in } \\
\text { Guangzhou and Shenzhen }\end{array}$ & 6265 & Less automobile and people & Good afforestation \\
\hline $\begin{array}{l}\text { Traffic line in Guangzhou } \\
\text { and Shenzhen }\end{array}$ & 18679 & many automobile and people & Lack of afforestation \\
\hline
\end{tabular}

